FOLIA POMERANAE UNIVERSITATIS TECHNOLOGIAE STETINENSIS

Folia Pomer. Univ. Technol. Stetin., Oeconomica 2019, 353(95)2, 33-40

Feliks M. STAWARCZYK

\title{
EQUITY AS ADDITIONAL PENSION PROVISION - WITH GERMANY AS AN EXAMPLE
}

\author{
Department of System Analysis and Marketing, West Pomeranian University of Technology \\ in Szczecin, Klemensa Janickiego 31, 71-270 Szczecin, Poland, ORCID: 0000-0001-6284-723x, \\ e-mail: feliks.stawarczyk@zut.edu.pl
}

\begin{abstract}
Summary. The aim of this article is to attempt an analysis and assessment of the significance of equity as an additional deposit instrument for those who wish to save funds for their future pensions. Statutory pensions are expected to be insufficient for future retirees to maintain a good standard of living. Their levels are bound to keep dropping, with the amount of pension contributions rising. Therefore, investments in equity and equity funds are seen as a method for breaching the pension gap. Accounting for the capital market in some highly-industrialized countries' pension systems has brought positive results.
\end{abstract}

Key words: pension system, equity, equity culture, capital market, investments.

\section{INTRODUCTION}

Globalization and ageing populations are the most significant challenges faced by European Union member states. Globalization decreases budgetary revenues due to the easiness with which businesses can move their operations to more profitable locations around the world. Social care efforts designed for the ageing societies are receiving less and less funds. At the same time, less money is paid to state budgets due to decreasing amounts of taxes on labor paid. On the other hand, the number of pensioners is growing. In Germany, for a long time statutory pension was perceived as the only - for most employees - pension system. However, according to forecasts the future pension will fall down to 40 percent or even less of its present level already in 2060 (Nur die Aktie 2016). For this reason, in order to ensure themselves a fair standard of living future retirees should undertake appropriate measures sufficiently in advance. They can take advantage of the rich experience gain by many other countries. This particularly applies to the successful practices of investing one's savings in equity or equity funds for the sake of ensuring their future pension. Depositing money in such instruments has in the longer term - of 30 to 40 years - been bringing higher rates of return than investment rates or interest rates on bonds. The overall conclusion is that this is the only method for maintaining the purchasing power of one's savings. The high profitability of equity investments makes pension benefits worked out in this way less susceptible to demographics. Moreover, as Australian experience shows a pension system supported by investment in corporate equity contributes to the stability of the financial and economic system as a whole, particularly during a global financial crisis. 
The article presents the German pension system facing demographic changes and points to the need for finding alternative additional sources of financing future pensions. This subject is equally topical in Poland.

\section{GERMAN THREE-PILLAR PENSION SYSTEM}

\section{Pension system reforms in Germany}

The modern German pension system was authored by Chancellor of Germany Otto von Bismarck (Bismarck Sozialgesetze 2014). For the first time, providing for the future of old-age employees was mentioned when introducing social provisions in the German Empire in 1881. The system, rolled out during the Chancellor's government, comprised three major components: sickness insurance (since 1883), accident insurance (since 1884) and pension insurance (since 1889).

The disability and old-age pension insurance was only available to those who reached the age of 70 . Importantly, life expectancy was 40 years at that time, while the minimal contribution period was 30 years. The employee's family did not inherit their contributed funds upon their death.

The pensions were financed by mandatory contributions paid by the employees and the employers in equal shares, as well as by state subsidies. Overall, the disability and old-age pension benefits were low and often failed to provide subsistence income (Bevoelkarungsentwicklung 2014). Their levels were contingent on the income gained, according to the so-called equivalence principle.

In 1916, the retirement age was lowered to 65 years. The pension insurance schemes as we know today were installed in 1957 by Chancellor of Germany Konrad Adenauer. That was when the capital method for funding pensions was replaced by the pay-as-you-go model. Also, the retirement age for women was lowered to 60 years, and a flexible retirement age for men was introduced. It became possible to retire at the age of 63 or continue professional activity until 65.

\section{Modern German pension system}

The present-day pension system operated in Germany (Table1) is basically founded on three pillars (Bächer 2016):

- 1st pillar - mandatory state pension insurance,

- 2nd pillar - occupational pension insurance,

- 3rd pillar - private pension insurance.

The first pillar, i.e. the statutory pension insurance, is a public mandatory pension insurance that almost all employees in Germany are subject to. The public pension system is financed by contributions paid in equal shares by employees and their employers. The pension benefits are paid from contributions made currently according to the pay-as-you-go model, whereby pensions are paid using funds contributed by professionally active persons.

In 2016, pension contributions accounted for 18.7 percent of the employee's annual gross salary (www.deutsche-rentenversicherung.de). Because of the insufficient level of funds from the contributions, it has become necessary to support the first-pillar pension system with state subsidies. 
Table 1. The three-pillar pension system in Germany

\begin{tabular}{|l|l|l|}
\hline \multicolumn{2}{|c|}{ Pension benefits } \\
\hline \multicolumn{1}{|c|}{$\begin{array}{c}\text { mandatory state pension } \\
\text { schemes }\end{array}$} & occupational pension schemes & private pension schemes \\
\hline $\begin{array}{l}\text { - state insurance } \\
- \text { farmer insurance }\end{array}$ & - direct promise & - banking products \\
$-\begin{array}{l}\text { civil servant and soldier } \\
\text { insurance }\end{array}$ & - direct insurance & - pension company \\
- self-employed insurance & - pension fund & \\
& - support fund & \\
\hline
\end{tabular}

Source: developed by the author based on: Bächer (2016).

The main objective of the statutory pension scheme is to ensure that average-earning employees have means of subsistence in the old-age. This objective, however, becomes less and less feasible due to demographic, economic and political causes.

While in the 1960s a single pension was paid for by three employees, this ratio is forecasted to be 1: 1 in 2040 (Nachschlagen). Also, there is also a distinct difference observed between revenues from employee contributions and the amount of pension benefits paid. In 2000, that difference was approx. 20 billion euros. In 2014, the state had to add over 40 billion euros from its budget to account for the gap. Such aid from the state is becoming more and more needed due to the fact that Germany's society is becoming increasing old.

On the one hand, the country's demographic situation has been impacted by the considerable drop in the fertility rate, which in 2015 was 1.5 - one of the lowest in the world (the rate's minimum level should be higher than 2). On the other hand, advances in medicine and the growing prosperity have been contributing to the increasing life expectancy. For a man born in 1960 life expectancy is 66 years, and for one born in 2013 it is 78 years (Entwicklung 2018).

Occupational pension schemes make up the so-called second pillar of the German pension system. The pillar comprises schemes offered by employers, while participation is voluntary.

The employers have five model schemes to choose from, with one being the direct promise (German: Direktzusage) operated within the enterprise. The other four schemes are operated by external entities. These are the direct insurance (German: Direktversicherung), pension companies (German: Pensionskassen), pension funds (German: Pensionsfonds) and support funds (German: Unterstützungskassen).

The direct promise boils downs to the employer paying a defined part of the employee's salary to the in-house pension pool. The money stays in the company, which is obliged to pay pension to the employee in the future. Therefore, the employee receives that part of their salary only several years later in the form of pension benefits. The amount of such benefits is dependent on the employee's seniority in the company and the level of their salary.

The direct insurance consists in the employer entering, in the name of the employees, into a life insurance or pension contract with an insurance company. The benefits are paid by the insurance company and not by the employer.

Pension companies are independently operating institutions providing life insurance, which may work for one or more enterprises. In general, the employers usually pay the contributions for their employees. 
Pension funds, as well, function as legally and economically distinct insurance companies. Contributions paid by employees to such funds are managed by financial managers having the power to deposit the money in any instrument of their choice, such as equity, bonds, investment fund units and real estate. Pension funds may offer higher rates of return than other alternative investments. However, the higher rates of return are associated with a higher investment risk. When seeking insurance from a fund, employees can choose the level of risk they are willing to accept. The amount of their pension will first of all be dependent on the revenue from capital investments.

Support funds are one of the oldest forms of occupational pension schemes. They are formed by legally and economically distinct insurance companies, which often trade as associations. The contributed capital can be invested in any deposit instruments. Where the gathered capital is insufficient to cover pension liabilities, the missing part must be contributed by the employer.

The third pillar of the German pension system comprises additional individual private pension schemes. The procedure here is to save funds using the capital market. The contributed capital, as well as the profit earned, belong to the savers, who can choose to either receive it in the form of life annuity or a one-off disbursement of the entire collected amount.

The state-subsidized Riester-Rente and Rürup-Rente schemes are two of the pension plans available under the third pillar. 'Riester pension', an option to gather funds within a private pension scheme, was launched in 2002 and named after the then Minister of Labor and Social Affairs, Walter Riester. Under this scheme, every contribution made by the employee entails a specific subsidy from the government. There are a range of Riester pension scheme types available. Rürup pension, in turn, is designed for high-income employees and for entrepreneurs who are not insured under the first pillar. Using this form of gathering funds brings, in particular, substantial tax benefits. In 2016 , as much as $82 \%$ of the contributed amount was tax deductible. By 2025 , this limit will have risen to $100 \%$. However, the inability to terminate or assign the contract is a deficiency to this form of saving. In the event of the beneficiary's death, should they be unmarried, the funds gathered within the scheme is lost. The pension cannot be disbursed before the age of 60 . For these reasons, this pension scheme is not very popular among German employees (www.bpb.de). Many German experts even believe that the country's private pension schemes are too complex for an average employee (Stocker 2019) and, therefore, bank deposits and insurance policies prevail as instruments used for saving funds for future pensions.

\section{EQUITY CULTURE IN GERMANY}

\section{Equity culture - the concept and its description}

Equity culture, in its wider sense, characterizes a society that treats equity as a financial instrument (Leven 1999). On the one hand, equity is of interest to the issuers, that is companies willing to gain capital for their business operations. On the other hand, equity is attractive to the investors willing to deposit their savings in a way that will bring profit. 
These investors are the so-called wide public, and comprise private persons or institutions such as investment funds, banks, insurance companies, enterprises, organizations, and others. Each of these investor groups has its unique expectations, interests and obligations. Most often, investors seek high rates of return on their equity investment, either in the short or long term.

Possession of equity carries a number of equity-related rights, such as to vote. The dealings of joint-stock company managers are supervised by the shareholders, which may lead to disputes, pressure or tensions. On the other hand, there is the society that evaluates, often critically, the companies' dealings in terms of, for instance, their environmental protection effort or their economic decisions. The mutual relationships between the different interest groups and their attitude to equity are, on a daily business, part of equity culture.

However, it must be stressed that equity is not yet a widely popular or significant cultural good in Germany (Sauter 2010; Warum 2011). The German equity culture has not advanced to an extent found in many other highly-developed countries (Die Aktie 2016).

The ratio of the value of all the given country's listed companies to its gross domestic product (GDP) is one of the most important indicators of the strength with which the capital market affects the nation's economic success. In 2016, the ratio for Germany was approx. $50 \%$. For the USA it was $147 \%$, i.e. almost three times as much. For Switzerland, it was four times as much, i.e. $213 \%$, and for France it was $87 \%$.

Germans only invest a mere $10 \%$ of their savings in equity (Mehr 2019, p. 4). In 2018 , equity was held by 10.3 million people, i.e. $16.2 \%$ of the overall population. Of this figure, 2.5 million held equity alone, 5.7 million held shares in equity funds alone, and over 2 million deposited their surplus money both in equity and equity funds (Zahl 2018, p. 3).

\section{Causes of Germans' poor interest in equity}

The relatively low interest among Germans in equity as a tool for depositing their funds is a matter of culture rather than reason (Deutsche 2018). There are a number of causes of this situation, most importantly (Aktienkultur 2018):

- the knowledge of historical crises,

- fear of losing money,

- fear of buying wrong equity,

- lack of knowledge of how to invest in equity,

- insufficient savings,

- risk aversion,

- low tolerance of investment uncertainty.

In particular, two traumatic capital market events from the past have left a lasting impression on the potential investors, namely the sale of Deutsche Telekom AG shares and the international stock market crash of 2007-2008. The shares of Deutsche Telekom AG, referred to as T-Aktie (T-Aktie 2003), were first issued through public offering in 1996. Their sale was preceded by an unprecedented advertising campaign. Telekom equity was hyped as "national", or "popular" (Berger 2014, p. 91). The promotion turned out to be very successful. The equity was purchased by 2 million investors, a third of whom were first-time buyers. This marked the 
beginning of stock market euphoria in Germany that lasted for a few years. Then, after a rapid growth in T-Aktie prices, their value dropped suddenly. The price per share, at its peak in March 2000, was 103 euros (with the issue price of approx. 30 euros). The year 2001 saw a global share plunge associated with the collapse of the so-called new economy myth, after which T-Aktie's prices have never even reached their issue value (presently, the prices range from 13 to 18 euros per share). Since 2001, approx. 3.9 shareholders have left the stock market, while at the market's peak there were 12.8 million shareholders and equity funds. This came as a true blow to the German equity culture (Schwarzer 2014).

Further stock market "turbulences" came during the economic and financial crisis of $2007-2008$. The $40 \%$ drop in share prices that occurred in 2008 only reassured Germans' belief that they should stay away from this type of transactions (Schlieker 2017).

\section{EQUITY IN THE PENSION SCHEME}

Studies of the profitability of various investment instruments in 15 countries over a period of the last 150 years have shown that real estate and equity have brought the highest rates of return, with a mean annual growth in value of $7 \%$. During the same time, bonds have grown by approx. $2 \%$ and bank deposits by a mere $0.3 \%$ in value, annually (Jonda 2017 ).

Many nations can already boast positive experiences with investing funds in equity for the purpose of ensuring future pensions (Kuhn 2019). Canadians and Americans make yearly revenues from equity investment as part of pension schemes reaching $10 \%$, while Swedes make 9\%. In Australia, the rate of return is 6\%. Denmark, the UK and the Netherlands usually enjoy a rate of return of $5 \%$, while in Germany the rate is 2 to $3 \%$, annually.

Therefore, equity appears to be a tool best placed to invest into under pension systems. It has the potential of making a substantial contribution to eliminating the negative effects of demographic changes on future pensions (Aktien 2017). The examples of the USA, the UK and Sweden show that equity investment as part of pension schemes has a positive impact on the development of equity culture (Stärkung 2018).

The first pillar, namely the statutory pension insurance, is the most popular of the German pension system pillars, with $75 \%$ of standard pensions covered by the funds gathered within it. The remaining $25 \%$ comes from other sources (Altersvorsorge 2019, p.11). This pension structure places Germany at the end of the raking of industrialized countries (Table 2), as in OECD nations $31 \%$ of the average pension comes from savings from the second and third pillars. One-third of the average Swedish retiree's pension comes from capital investment. In Switzerland, equity revenue constitutes almost half of the retirement benefit. Even higher shares are observed in English-speaking countries, where traditionally the pension systems have been strongly anchored in the capital market. This figure is almost $50 \%$ in Canada and the USA, while in the UK it is as much as $58 \%$. The ranking is topped by the Netherlands and Denmark with 70 and $83 \%$, respectively, of the pension amount contributed by revenue from equity investment. Australia can be treated as a phenomenon among these countries, as the share of revenue from equity investment accounts for $100 \%$ of the pension amount. 
Table 2. Funding for standard pensions (percentage-wise)

\begin{tabular}{|l|c|c|}
\hline \multicolumn{1}{|c|}{ Country } & $\begin{array}{c}\text { Statutory pension insurance } \\
\text { (contributions and taxes) }\end{array}$ & Voluntary pension insurance \\
\hline Germany & 75 & 25 \\
OECD - mean & 69 & 31 \\
Sweden & 66 & 34 \\
Switzerland & 57 & 43 \\
Canada & 55 & 45 \\
USA & 54 & 46 \\
UK & 42 & 58 \\
Netherlands & 30 & 70 \\
Denmark & 17 & 83 \\
Australia & - & 100 \\
\hline
\end{tabular}

Source: developed by the authors based on Altervorsorge (2019).

\section{CONCLUSION}

Ensuring a high standard of living in retirement for the future generations is a particularly important task in view of the demographic changes that, to varying degrees, affect all industrialized countries. Some of them have already found solutions that will allow their retirees to maintain a high standard of living, also in the future. The idea that investing into your future pension should be oriented towards utilizing the stock market should become part of education and savings allocation strategies (Hock 2016), as well as equity culture. As the experience of many countries shows, equity contributes to ensuring and maintaining a fair standard of living, although it must be remembered that such investments require a long-term investment horizon.

\section{REFERENCES}

Aktien in Deutschland fördern 2017. Deutsches Aktieninstitut, www.dai.de, access: 5.12.2019.

Aktienkultur in Deutschland. 2018. Bevölkerungsbefragung, Pro Aktie, www.aktion-pro-aktie.de, access: 10.12.2019.

Aktienkultur: Deutschland darf nicht weiter zurückfallen, www.deutsche-boerse.com, access: 20.11.2019.

Altersvorsorge mit aktien zukunftsfest machen 2019. Frankfurt am Main, Studien des Deutschen Aktieninstituts.

Bächer F., Kistler E. 2016. Das 3-Säulen-System der Alterssicherung in Deutschland im Überblick, http://www.bpb.de/politik/rentenpolitik/222498/3-sauelen-system-der-alterssicherung, access: 20.09.2019.

Berger J. 2014. Wem gehört Deutschland? Frankfurt/Main, Westend.

Deutsche Sparer: zu wenig Aktien! Blickpunkt: Aktienkultur in Deutschland. 2018. LBBW, www.lbbw.de, access: 2.12.2019.

Die Aktie im internationalen Vergleich so steht es um die Aktienkultur wirklich 2018. Frankfurt am Main, Deutschland größte Direktbankenstudie.

Hock M. 2016. Nur die Aktie kann die Rente retten, http://www.faz.de/aktuell/firmen/meine-finanzen/ /vorsorgen-fuer-das-alter/deutsches-aktieninstitut-fordert-staerkung-der-riester-rente-14562203.html, access: 10.12.2019.

Jonda O., Knoll K., Kuvshinov D., Schularick M., Taylor A.M. 2017. The rate of return on everything 1870-2015, Federal Reserve Bank of San Francisco, Working Paper.

Kuhn N. 2019. Altersvorsorge mit Aktien, Kurvenlage, 1. Halbjahr, www.dai.de, access: 30.11.2019. 
Lebenserwartung in West und Ost Deutschland, www.lebenserwartung.info/index-Dataien/leden.html, access: 8.12.2019.

Leven F.J. 1999. Aktienkultur in Deutschland - auf dem richtigen Weg. Ed. N. Frei et.al., Wiesbaden, Aktie im Fokus, Betriebswirtschaften, Gabler.

Mehr Aktionäre in Deutschland. 2019. Frankfurt am Main, Studien des Deutschen Aktieninstituts.

Sauter N. 2010. Das schwache Pflänzen Aktienkultur, Allianz, Economic Research \& Corporate Development, Working Paper.

Schlieker K. 2017. Deutsche Börse will Verstäendnis für Aktienanlage fördern, Wiesbaden Kurier, www.wiesbaden-kurier.de/wirtschaft-regional/deutsche-boerse-will-verstaendnis-für-Aktienanlage, access: 20.10.2019.

Schwarzer J. 2014. Plädoyer für die Aktie: Das Märchen vom Volk der Aktienmuffel, http://www.nadelsblatt.com, access: 19.12.2019.

Stärkung der Aktienkultur und Endbürokratiesierung - das Resept für mehr Börsengänge 2018. Frankfurt am Main, Pressenmitteilung, DAl.

Stocker F. 2019. Altersvorsorge nach SkandinavischerArt, www.welt.de/print/die-finanzen/artikle/ /190557017/Altersvorsorge-nach-skandinavischerArt.html, access: 15.07.2019.

T-Aktie: Chronik des Niedergangs 2003. Manager Magazin, https://ww.manager-magazin.de/ /finanzen/artikel/a-149279.html, access: 16.11.2019.

Warum hat Deutschland keine Aktienkultur? www.aktien-tagebuch.de/2011/05/aktienkulturdeutschland, access: 12.11.2019.

Zahl der Aktienbesitzer in Deutschland Steigt auf 10,3 millionen. 2018. Deutschen Aktieninstituts, www.dai.de, access: 15.11.2019.

www.bpb.de/nachschlagen/zahlen-und-fakten/soziale-situation-in-deutschland/61857/einnahmenund-ausgaben, access: 20.07.2019.

www.bpb.de/politik/innenpolitik/rentenpolitik/149331/vorsorgeprodukte, access: 19.10.2019.

www.bpb.de/politik/innepolitik/rentenpolitik/141486/bismarcks-sozialgesetze, access: 25.10.2019.

\section{AKCJE JAKO FORMA DODATKOWEGO ZABEZPIECZENIA EMERYTALNEGO NA PRZYKŁADZIE NIEMIEC}

Streszczenie. Celem artykułu jest próba analizy i oceny znaczenia akcji jako dodatkowego instrumentu lokacyjnego dla oszczędzających na przyszłą emeryturę. Przewiduje się, że dla przyszłych emerytów ustawowa emerytura nie będzie wystarczająca do utrzymania dobrego standardu życia. Poziom emerytur będzie spadał, a składki emerytalne będą rosły. Dlatego też w inwestycjach $w$ akcje i fundusze akcyjne dostrzega się sposób na zlikwidowanie luki emerytalnej. Uwzględnienie rynku kapitałowego w systemach emerytalnych niektórych wysokouprzemysłowionych krajów przyniosło pozytywne efekty.

Słowa kluczowe: system emerytalny, akcje, kultura akcyjna, rynek kapitałowy, inwestycje. 